\title{
Immediate impacts of COVID-19 on the aquaculture value chain in Ghana
}

\author{
Catherine Ragasa, Sena Amewu, and Seth Asante
}




\section{TABLE OF CONTENTS}

Abstract

1. Introduction

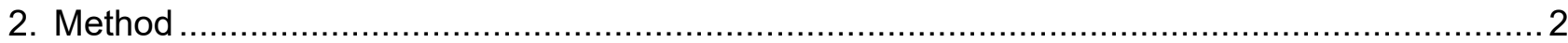

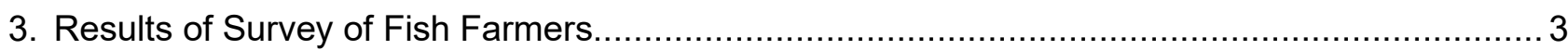

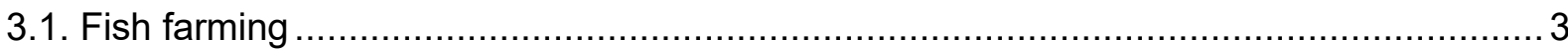

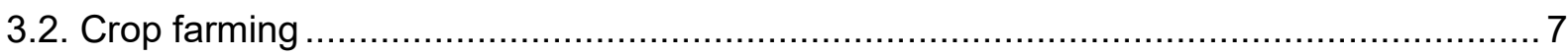

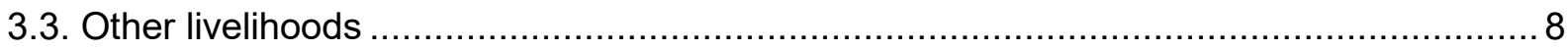

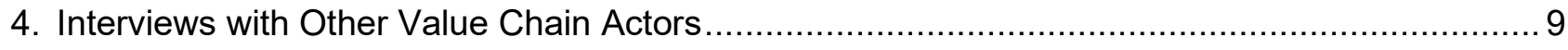

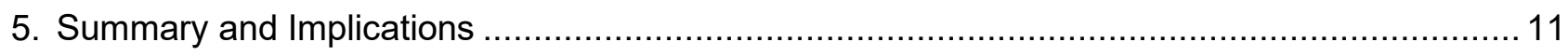

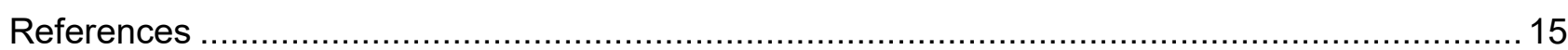

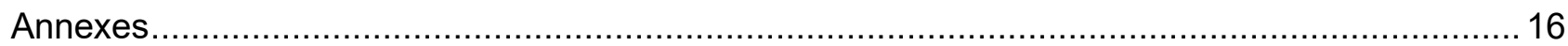

\section{LIST OF TABLES}

Table 1. Effects of COVID-19 crisis in Ghana on fish farming and access to farm inputs, percent of fish farmers surveyed

Table 2. Anticipated changes in stocking, marketing, and consumer demand, percent of fish farmers surveyed.

Table 3. Actual and anticipated effects of the COVID-19 crisis on crop farming and marketing, percent of fish farmers surveyed

Table 4. Effects of the COVID-19 crisis on other livelihoods and household income of surveyed fish farmers.

Table 5. Changes in tilapia purchases and price during the COVID-19 crisis, percent of consumers

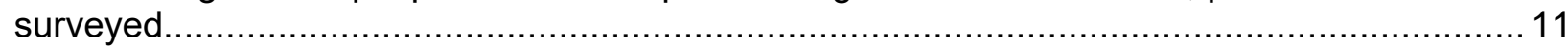

Table 6. Summary of effects of the COVID-19 crisis on tilapia value chain actors in Ghana ........ 12

Annex Table 1. Demographic statistics for the samples for the 2020 phone survey and 2018 faceto-face survey of consumers in Accra, percent of respondents....

Annex Table 2. Demographic statistics from the 2020 farmer phone survey and the 2019 face-toface survey of small-scale farmers in major aquaculture and crop producing regions, percent of respondents

Annex Table 3. Effects of fish mortality in Lake Volta due to infectious spleen and kidney necrosis virus (ISKNV) on tilapia stocking and production, percent of cage farmers .......................... 17

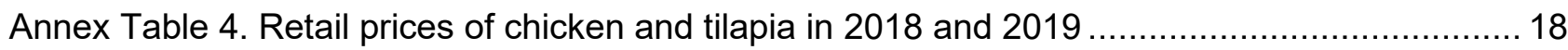

Annex Table 5. Comparison of prices of selected food items before the COVID-19 crisis and after lockdown, reports of consumers surveyed in Accra who reported price changes.

Annex Table 6. Food consumption and changes in consumption due to COVID-19 crisis reported by consumers surveyed in Accra....

Annex Table 7. Food consumption and changes in consumption due to COVID-19 crisis reported by fish farmers surveyed 


\section{LIST OF FIGURES}

Figure 1. Engagement in fish farming or fish harvesting during COVID-19 crisis ........................ 4

Figure 2. Fish farmers reporting having experienced difficulty in accessing inputs during COVID-19

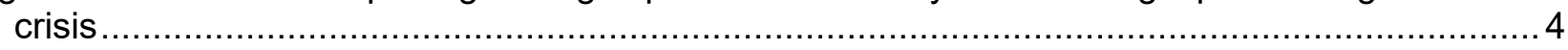

Figure 3. Observed and anticipated difficulty in selling tilapia among fish farmers surveyed .......... 5

Figure 4. Effects of COVID-19 crisis on fish marketing and sales among fish farmers surveyed ..... 6 


\section{ABSTRACT}

Ghana's aquaculture sector is among the recent success stories of fast-growing agricultural value chains in Africa south of the Sahara. The sector has also shown its vulnerability, with the infectious spleen and kidney necrosis virus spreading through tilapia farms in Lake Volta in late 2018. The global COVID-19 human pandemic reached Ghana in early 2020, affecting the sector directly and indirectly. Using a value chain approach, phone interviews were conducted with 369 small-scale fish farmers in six major producing regions, with 12 other value chain actors, and with 423 consumers in the capital, Accra, to assess the impact of COVID-19 on the sector. All value chain actors interviewed reported being affected directly by COVID-19 related restrictions on movement and indirectly by reduced demand for tilapia because of closures in the tourism and hospitality industries, important consumers of fresh tilapia. The crisis has reduced incomes for most actors along the aquaculture value chain and is anticipated to reduce future production. Most fish farmers surveyed were affected by disruptions in input and output markets. Two-thirds of the sample farmers were growing fish and 6 percent were harvesting when the COVID-19 crisis hit. Fifty-four percent of those growing fish experienced difficulties in accessing inputs - mainly fish feeds. Of those harvesting during the crisis, most experienced difficulty in selling their fish mainly because of low demand from buyers, lower tilapia prices, and higher transportation costs than before COVID-19. Income losses among fish farmers, including from other sources, such as crop farming, wage employment, and other own businesses, limits the funds that they have available to finance fish farming operations or to invest in future production capacity. Likewise, reduced incomes and purchasing power of consumers is causing a sharp decline in demand for fish.

Keywords: aquaculture; COVID-19; value chain; food system; impact; Africa 


\section{INTRODUCTION}

Ghana's aquaculture sector is among the recent success stories of fast-growing agricultural value chains in Africa south of the Sahara (Kassam and Dorward 2016; Ragasa et al. 2018). In 2018, the sector produced 76,000 tons of tilapia valued at $\$ 200$ million and provided employment and income for thousands - from feed and fingerling producers to fish feeders, monitors, processors, and traders. Most of those employed in the value chain are youth, and many women are involved in all stages, especially in processing and trading (Kassam and Dorward 2016; Ragasa et al. 2020). The sector has strong backward and forward linkages and a large multiplier effect on local economic growth and poverty reduction (Kassam and Dorward 2016). To accelerate the growth of the sector and its development impact, the government has launched the Aquaculture for Food and Jobs program, building on its flagship program on Planting for Food and Jobs.

The last 18 months also show the vulnerability of the sector. In late 2018, infectious spleen and kidney necrosis virus (ISKNV) spread through tilapia farms in Lake Volta, causing high mortality of fish in cage systems (Ramírez-Paredez et al. 2019). The outbreak was likely triggered by poor management practices, seasonal water quality issues, and illegal imports of foreign tilapia strains. Then, in March 2020, just as the sector started to bounce back, the COVID-19 pandemic and its related lockdowns and restrictions began affecting the value chain. To mitigate the spread of the virus in Ghana, the President directed that borders be closed, social distancing be practiced, prohibited public gatherings, and put in place partial lockdowns in Greater Accra, Kasoa, and Ashanti regions. Demand for fresh tilapia dropped significantly as a result of these lockdowns, particularly due to restrictions on tourism and restaurant and hotel closures. Despite the gradual lifting of restrictions in recent months, the tourism and hospitality industry remain depressed and offices and businesses have just started reopening cautiously.

Ghana's aquaculture value chain is particularly vulnerable to the COVID-19 crisis and related response measures for several reasons. With respect to consumption demand, it relies heavily on hotels and restaurants as well as more informal chop bars or tilapia joints, all of which closed during the partial lockdown and then reopened with substantially reduced operations. Because tilapia is relatively expensive in Ghana - two to three times as expensive as imported chicken (Ragasa et al. 2018; Andam et al. 2019) - it is among the first purchases given up when incomes fall. Studies on the immediate impact of COVID-19 in Ethiopia, India, and Myanmar have shown decreased consumption of more expensive foods, even if more nutritious, such as meat, fish, dairy, and vegetables (Harris et al. 2020; Headey and Ruel 2020; Hirvonen et al. 2020; Lambrecht et al. 2020). On the production side, the sensitivity of fish mortality and productivity to feed availability and timing make any disruption in feed access potentially detrimental to fish farming operations. Fingerlings and fish are highly perishable, so any disruption in transportation services and in Ghana's limited cold chain and processing facilities makes aquaculture susceptible to fingerling and fish mortality, food wastage, and opportunistic behavior.

To understand the impact of the current COVID-19 crisis on the aquaculture value chain, researchers from the International Food Policy Research Institute (IFPRI) paired information collected through a rapid assessment done in May 2019 using phone interviews with 12 actors along the value chain with the results of a formal phone survey done in June 2020 of 369 fish farmers and 423 consumers. The assessment shows that the COVID crisis directly affects the sector via falling tilapia demand, reduced production and sales, disruptions in input and output markets and transportation, and lower incomes of different actors along the chain. Income losses among fish farmers, including those from other livelihood sources (crop farming, wage employment, and own business), limits the funds that they have available to finance fish farming 
operations or investments in future production capacity. Likewise, reduced incomes and purchasing power of consumers is causing a sharp decline in the demand for fish.

\section{METHOD}

The method used is a phone survey of fish farmers and consumers, building on a baseline survey of 603 small-scale fish farmers in the major aquaculture regions of Eastern, Volta, Ashanti, and Brong Ahafo (now recently sub-divided into Bono, Bono East, and Ahafo regions) conducted in June 2019 (Ragasa et al. 2020) and a survey of 1,200 consumers in various market types in Accra conducted in September 2018 (Ragasa et al. 2019; Andam et al. 2019). The samples for the phone surveys in June 2020 were 369 small-scale fish farmers and 423 consumers. The characteristics of the phone survey and baseline survey samples are similar (Annex Tables 1 and 2).

The 2019 baseline data on fish farmers consist of a census of active small-scale tilapia farmers in the six major producing regions. Earthen ponds and cages are the two major fish farming systems in Ghana. Ashanti and Brong Ahafo are the regions in which are found major cage tilapia producers and also where the majority of the medium- and large-scale cage farmers around Lake Volta are located. Eastern and Volta regions are where most pond farmers are located. Smallscale farmers are defined as those producing less than 50 metric tons per year, which is consistent with Environmental Protection Agency, Fisheries Commission, and CSIR-Water Research Institute definitions (Karikari et al. 2016). ${ }^{1}$ News articles had focused on the large drop of sales and revenue of large scale fish farmers (Kudah 2020). This paper complements those news articles with a focus on small-scale farmers. Even within the category of small-scale farmers, pond and cage farmers are generally different. Based on the baseline survey, cage farmers are more likely to be in the lower asset quintiles, with lower wealth levels, than the pond farmers (Ragasa et al. 2020). Most pond farmers own cropland and so are also engaged in crop farming and other income-generating activities. Cage farmers are more likely to depend solely on fish farming for their household income than do pond farmers.

For these reasons, respondents in the baseline survey were stratified into cage and pond farmers, and then by gender and age group. Because the baseline survey included only a few cage farmers and female and youth farm managers, we included them all in the phone survey sample. The rest of the phone survey comprises a random selection of male, non-youth pond farmers from the baseline survey. There is no systematic difference in terms of wealth distribution between male and female and between youth and non-youth respondents, so no adjustments or weights were used to adjust for the oversampling of female and youth respondents. For the descriptive results pertaining to the combined cage and pond farmers, we adjusted the oversampling of cage farmers by applying higher weights to pond farmers and a lower weight to cage farmers to maintain the representativeness of the sample. ${ }^{2}$

For the phone survey of consumers in Accra, the sample was first stratified by tilapia, chicken, and rice shoppers - given that these consumers were previously selected as actual buyers of these focus foods during the consumer exit survey - and then randomly selected within each commodity strata. Different types of markets - from traditional markets to cold stores to

\footnotetext{
1 There is no updated list of active medium- and large-scale tilapia farmers. An older list from the Fisheries Commission indicates 50 farmers with more than 20 cages, which can be considered medium- or large-scale farmers, assuming an average production of 2.5 tons per cage. These farmers are mainly cage farmers in the Akosombo zone and Volta region. Of the 50 farmers, about 15 are mainly hatcheries or integrated hatchery-grow-out farms.

2 In the baseline survey, there were 131 of the 603 farmers surveyed were cage farmers (22 percent). Two farmers who have both cages and ponds were counted as cage farmers as most of their production was from cages. In the phone survey, 83 of the 365 farmers in the sample were cage farmers (29 percent). Of the 238 baseline farmers not surveyed, 38 (20 percent) were cage farmers. In the descriptive results, we apply as sampling weights the inverse proportion $-365 / 81=3.4$ for cage farmers and $238 / 48=5.0$ for pond farmers.
} 
supermarkets - catering to all types of households were targeted for the consumer survey in 2018. The sample for both the 2018 survey and the 2020 phone survey was similar in several demographic characteristics to those for households included larger surveys in Accra (Ragasa et al. 2019; Andam et al. 2019). There is no systematic difference in wealth distribution across households between the 2018 and the 2020 phone surveys (Annex Table 1).

To obtain insights from other value chain actors, the fish farmer and consumer surveys were complemented by key informant phone interviews with two staff of breeding institutions, five hatchery operators, three feed producers and importers, one tilapia trader, and one tilapia retailer.

Almost all respondents during the baseline surveys reported telephone numbers. Only four fish farmers (less than 1 percent) and 72 consumers ( 5 percent) either did not have a cell phone or did not provide a telephone number. For the survey of fish farmers, one percent refused to respond, saying that they were no longer involved in fish farming. Another 16 percent had telephone numbers that did not work. There was only one refusal for the consumer survey. There were no systematic differences in terms of wealth distribution or region of origin between those surveyed and those who refused or whose telephone numbers were not working.

The phone survey was approved by the ethical review board of IFPRI. Eight enumerator-callers recruited and managed by the FMMS survey firm were trained for two days to implement the phone survey under the supervision of a senior research officer from IFPRI. Respondents were offered GHC 10 as phone credit after the interview. ${ }^{3}$ The phone surveys lasted 30 minutes on average. Questions included respondents' experiences with the COVID-19 crisis and response measures; its effect on their fish farming, crop farming, and other livelihoods; and their perceptions about the future of Ghana's aquaculture. Respondents were asked to compare situations before COVID-19 (January \& February 2020), during lockdown (March \& April), and after lockdown (May \& June). For some questions, respondents compared the situation during COVID-19 to the same time in 2019.

The analysis is mainly descriptive using tables and figures, complemented by narratives from the key informant interviews. We differentiate between cage and pond system and by region. Because of their similarities, in presenting our results, we group together the pond fish farmers of Volta and Eastern regions because of their proximity to each other and small sample sizes.

\section{RESULTS OF SURVEY OF FISH FARMERS}

\subsection{Fish farming}

One-third of the sample cage farmers did not grow tilapia during the COVID-19 crisis (March to May 2020). Mainly because of the effects of ISKNV, 10 percent of respondents had stopped fish farming and 63 percent had reduced their stocking and operations by at least 50 percent (Annex Table 3). Forty percent of the sample pond farmers in Eastern and Volta and 18 percent in Ashanti and Brong Ahafo also did not grow fish during the first months of the crisis.

${ }^{3}$ Ghanaian cedi $(\mathrm{GHC}):$ US $\$ 1.00 \approx \mathrm{GHC} 5.75$, mid-2020. 
Figure 1. Engagement in fish farming or fish harvesting during COVID-19 crisis

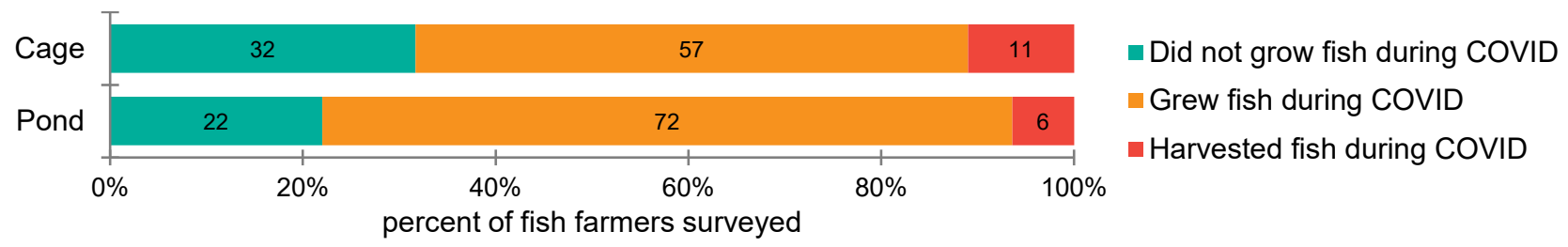

Source: IFPRI/FMMS phone survey of fish farmers (June 2020).

Two-thirds of the sample farmers were growing fish when COVID-19 hit (Figure 1). Fifty-three percent of those growing fish experienced difficulties in accessing inputs during the COVID-19 crisis, with the highest proportions being in the Brong Ahafo area and the lowest in Eastern and Volta regions (Figure 2).

Figure 2. Fish farmers reporting having experienced difficulty in accessing inputs during COVID-19 crisis

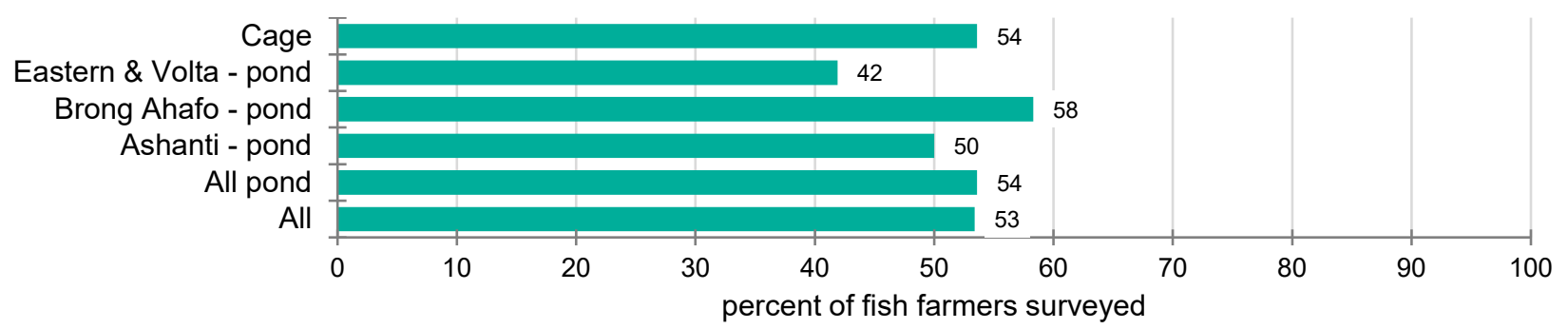

Source: IFPRI/FMMS phone survey of fish farmers (June 2020).

Table 1. Effects of COVID-19 crisis in Ghana on fish farming and access to farm inputs, percent of fish farmers surveyed

\begin{tabular}{|c|c|c|c|c|c|c|}
\hline \multirow[b]{2}{*}{ Indicators } & \multirow[t]{2}{*}{ All } & \multicolumn{4}{|c|}{ Pond } & \multirow[t]{2}{*}{ Cage } \\
\hline & & $\begin{array}{c}\text { All } \\
\text { pond }\end{array}$ & Ashanti & $\begin{array}{l}\text { Brong } \\
\text { Ahafo }\end{array}$ & $\begin{array}{l}\text { Eastern } \\
\& \text { Volta }\end{array}$ & \\
\hline \multicolumn{7}{|l|}{ Experienced difficulty in accessing ... } \\
\hline Fingerling & 15 & 14 & 16 & 14 & 8 & 23 \\
\hline Feed & 97 & 97 & 100 & 96 & 92 & 97 \\
\hline Fertilizer, lime, agrochemicals, drugs & 11 & 14 & 26 & 11 & 0 & 3 \\
\hline Farm machinery & 13 & 14 & 7 & 15 & 31 & 7 \\
\hline Others & 1 & 1 & 0 & 1 & 0 & 0 \\
\hline \multicolumn{7}{|l|}{ Reported changes in input prices } \\
\hline No change & 28 & 27 & 29 & 26 & 29 & 30 \\
\hline Increased & 60 & 59 & 60 & 61 & 48 & 63 \\
\hline Decreased & 0 & 0 & 0 & 0 & 0 & 2 \\
\hline Do not know & 12 & 14 & 11 & 13 & 23 & 5 \\
\hline \multicolumn{7}{|c|}{ Experienced difficulty in hiring labor during COVID } \\
\hline No difficulty & 60 & 55 & 52 & 54 & 68 & 79 \\
\hline With difficulty & 20 & 23 & 26 & 24 & 16 & 11 \\
\hline Did not hire labor & 19 & 22 & 23 & 23 & 16 & 11 \\
\hline \multicolumn{7}{|l|}{ Reported changes in wages } \\
\hline No change & 58 & 61 & 69 & 53 & 80 & 33 \\
\hline Increased & 18 & 16 & 19 & 17 & 0 & 33 \\
\hline Decreased & 25 & 24 & 13 & 30 & 20 & 33 \\
\hline Changed aquaculture practices & 34 & 36 & 36 & 39 & 19 & 29 \\
\hline Observations & 369 & 282 & 76 & 154 & 52 & 77 \\
\hline
\end{tabular}

Source: IFPRI/FMMS phone survey of fish farmers (June 2020). 
Of those fish farmers experiencing difficulty in accessing inputs, almost all experienced difficulty accessing feeds. Farmers also reported difficulty accessing fingerlings, fertilizers and other chemicals, and farm machinery (Table 1). Fifty-nine percent reported increases in input prices, particularly for feed, with a lower proportion of farmers reporting increases in Eastern and Volta, likely due to their proximity to major feed producers and importers. The average increase in feed prices was roughly GHC 2.00 per kilogram. In 2019, the average price for starter feed was GHC 19/kg and for grow-out feed, GHC 4.25/kg. Between January and June, the average fingerling price rose $\mathrm{GHC} 0.27$ per piece. The average price for fingerlings in 2019 was between GHC 0.15 and $\mathrm{GHC} 0.80$, depending on the fingerling size, location, and hatchery.

Fifty-four percent of pond farmers and 11 percent of cage farmers experienced difficulty in accessing labor for fish farming. Several respondents said, "Workers did not come to work due to fear of contracting COVID-19." One farmer said, "It was more difficulty to maintain and hire workers because of loss of income from fish farming and other livelihoods." Most sample farmers did not experience any changes in wages, although 16 percent did reported increases in fish farm wages. Average wages before COVID-19 (January) were GHC 30.00/day and GHC 363.00/month. Half of respondents reported paying daily wages. Of these, although some reported decreases in wages, the average change in wages was an increase of $\mathrm{GHC} 2.00 /$ day. For the half of respondents that reported paying monthly wages, the average change in monthly wages was a decrease of GHC 98.00/month during lockdown and of GHC 89.00/month after lockdown compared to before COVID-19 in January.

One-third of respondents changed some of their aquaculture practices in response to the COVID-19 crisis, with higher proportions of farmers in Ashanti and Brong Ahafo regions changing practices than in Eastern and Volta. The main adjustments were reducing feeding, using ownproduced feeds instead of buying commercial feeds, and reducing hired labor.

Figure 3. Observed and anticipated difficulty in selling tilapia among fish farmers surveyed

(a) Actual difficulty, among those selling

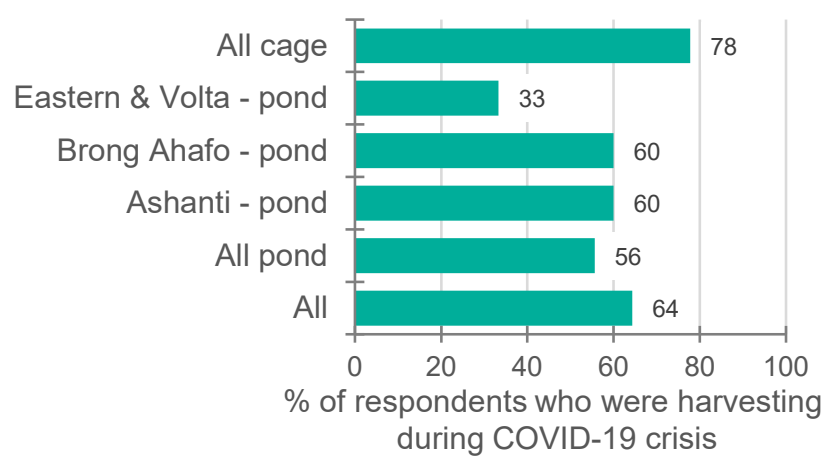

Source: IFPRI/FMMS phone survey of fish farmers (June 2020). (b) Anticipated difficulty, among those farming

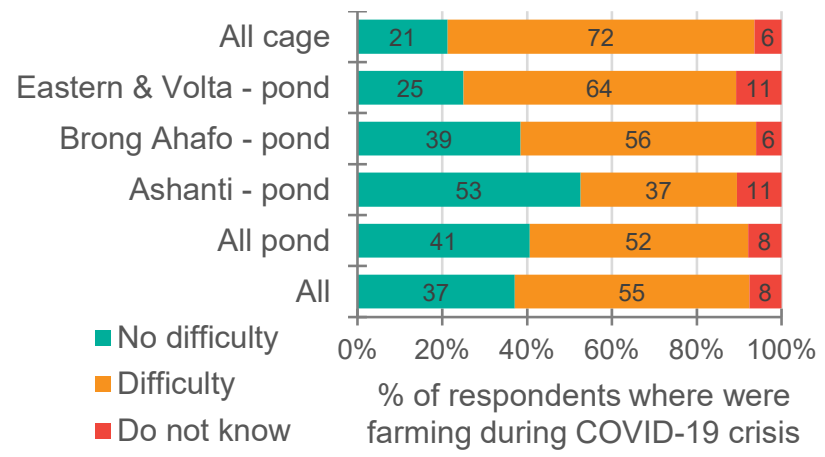

Few farmers harvested and sold fish during the COVID-19 crisis (March to June 2020) (Figure 1). Of those harvesting, 56 percent of pond farmers and 78 percent of cage farmers experienced difficulties in selling their fish (Figure 3). Higher proportions of pond farmers in Ashanti and Brong Ahafo regions than in Eastern and Volta experienced difficulty selling. The reasons reported for these difficulties were lower demand or no buyers, lower tilapia prices, and higher transportation costs (Figure 4). One farmer said, "Buyers are afraid of their movements to and from the production centers."

Farmers about to harvest fish to sell were told by aggregators to wait. "Most farmers were expecting to sell fish during the Easter celebration, which didn't happen due to the lockdown. Most of them were forced to sell the fish at lower prices after the lockdown," said a fish feed producer. 
Farmers have some flexibility to keep tilapia in their cages or ponds for a bit longer, but doing so means additional costs of continued feeding and higher risk of exposure to diseases and natural calamities. Large farms with cold storage may harvest and store, but small-scale farmers - most fish farmers in the country - do not have such facilities. Many farmers were forced to sell their tilapia at lower prices - one farmer reported reduced sales price from an average price of GHC 14.50/kg before the COVID-19 crisis to GHC 12.00/kg during the COVID-19 crisis for regular size 1 tilapia.

Figure 4. Effects of COVID-19 crisis on fish marketing and sales among fish farmers surveyed

(a) Reasons given for difficulties in selling, percent of those selling during COVID-19 crisis

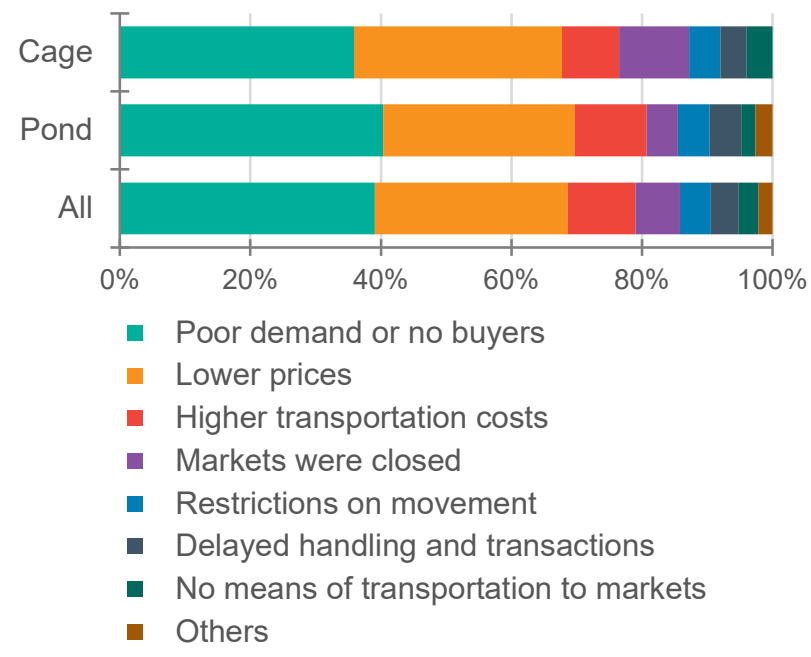

(b) Anticipated changing market outlet, percent of those farming during COVID-19 crisis

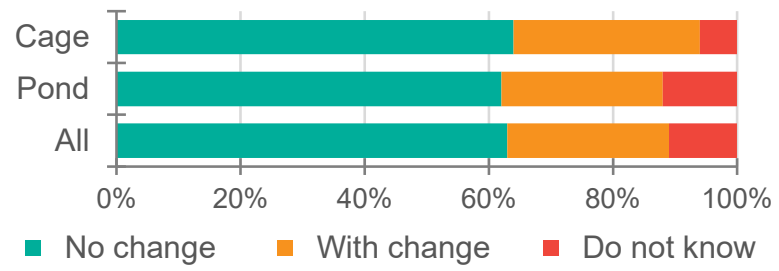

(c) Market outlet before and after lockdown, percent of fish farmers surveyed

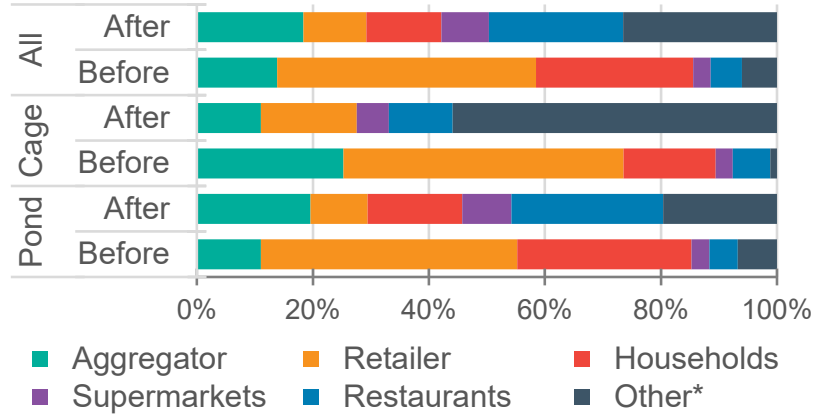

Source: IFPRI/FMMS phone survey of fish farmers (June 2020).

Note: * "Other" responses include farmers planning to focus on institutional buyers, e.g., schools, invest in cold chain facilities, or find international buyers.

An initial decrease in prices during lockdown resulted from distressed selling - growers with tilapia to sell were just trying to sell off their fish even at much reduced prices. Sellers also experienced some logistical challenges, including higher transportation costs, and the possibility of opportunistic behavior of some actors along the chain, resulting in the observed increases in tilapia prices in the market.

Of those selling, 25 percent in the Brong Ahafo area reported changing their principal market outlet; farmers in other regions did not. In terms of anticipated market outlet, 26 percent anticipate changing their market outlet (Figure 4). Pond farmers plan to shift from a heavy reliance on retailers to directly supplying households and institutional buyers (e.g., schools). Cage farmers anticipate moving from aggregators and retailers to more diversified outlets, such as increasing direct sales to supermarkets and restaurants. Others also mentioned investing in cold storage, processing, or value addition or finding international buyers.

In terms of perceptions of future production and demand, 82 percent of the sample fish farmers planned to stock or restock during the next cycle, which is encouraging (Table 2). Around 40 percent anticipate increases in consumer demand and prices, while 30 percent anticipate decreases in tilapia demand and 38 percent anticipate declines in prices. These responses 
indicate an opportunity to disseminate timely market intelligence to guide the production and investment decisions by fish farmers and other aquaculture value chain actors.

Table 2. Anticipated changes in stocking, marketing, and consumer demand, percent of fish farmers surveyed

\begin{tabular}{|c|c|c|c|c|c|c|}
\hline \multirow[b]{2}{*}{ Indicators } & \multirow[t]{2}{*}{ All } & \multicolumn{4}{|c|}{ Pond } & \multirow[t]{2}{*}{ Cage } \\
\hline & & $\begin{array}{c}\text { All } \\
\text { pond }\end{array}$ & Ashanti & $\begin{array}{l}\text { Brong } \\
\text { Ahafo }\end{array}$ & $\begin{array}{l}\text { Eastern } \\
\text { \& Volta }\end{array}$ & \\
\hline Plans to stock & 82 & 82 & 78 & 84 & 84 & 80 \\
\hline Do not plan to stock & 8 & 7 & 9 & 6 & 8 & 10 \\
\hline Do not know yet if will stock or not & 10 & 11 & 13 & 10 & 8 & 10 \\
\hline Plan to stock is affected by COVID-19 & 33 & 33 & 34 & 31 & 39 & 35 \\
\hline \multicolumn{7}{|c|}{ Anticipated change in consumer demand due to COVID-19: } \\
\hline No change & 14 & 14 & 21 & 12 & 12 & 12 \\
\hline Increase & 40 & 42 & 41 & 40 & 48 & 35 \\
\hline Decrease & 30 & 37 & 29 & 41 & 35 & 50 \\
\hline Do not know & 6 & 7 & 9 & 7 & 6 & 2 \\
\hline \multicolumn{7}{|c|}{ Anticipated change in tilapia price due to COVID-19: } \\
\hline No change & 13 & 14 & 17 & 13 & 10 & 10 \\
\hline Increase & 41 & 42 & 43 & 38 & 52 & 37 \\
\hline Decrease & 38 & 36 & 25 & 42 & 33 & 49 \\
\hline Do not know & 8 & 9 & 15 & 8 & 6 & 5 \\
\hline Observations & 369 & 282 & 76 & 154 & 52 & 77 \\
\hline
\end{tabular}

Source: IFPRI/FMMS phone survey of fish farmers (June 2020).

\subsection{Crop farming}

Most fish farmers are also crop farmers. Two-thirds of the respondents had cropland aside from their fish farm, and 79 percent of those with cropland grew some crops during the minor season that was underway when the COVID-19 crisis hit. The main crop grown is maize, although some farmers also grow cassava, plantain, and cocoa.

Of those harvesting crops, 34 percent experienced difficulty selling (Table 3). Of those growing crops, 43 percent experienced or anticipated difficulty accessing inputs. These difficulties are seen mainly for fertilizer and agrochemicals, but some also reported difficulty in accessing seeds and farm machinery.

Many farmers changed their cropping practices. Most respondents said they reduced their fertilizer use and used more animal manure or organic waste. Some also used less agrochemicals, substituting neem and other biopesticides. Some weeded more frequently because of reduced use of agrochemicals, whereas others reduced their use of family or hired labor.

Farmer responses also reveal some differences by crop. For example, of the two most common crops planted during the period of study - maize and cocoa - more respondents experienced difficulty selling cocoa than selling maize. However, more respondents anticipated increased demand and improved prices for cocoa than for maize. More farmers growing maize experienced or anticipated difficulty in accessing inputs. More respondents in Brong Ahafo, Volta, and Eastern regions than in Ashanti experienced or anticipated difficulty accessing inputs. 
Table 3. Actual and anticipated effects of the COVID-19 crisis on crop farming and marketing, percent of fish farmers surveyed

\begin{tabular}{|c|c|c|c|c|c|c|}
\hline \multirow[b]{2}{*}{ Indicators } & \multirow[t]{2}{*}{ All } & \multicolumn{4}{|c|}{ Pond } & \multirow[t]{2}{*}{ Cage } \\
\hline & & $\begin{array}{l}\text { All } \\
\text { pond }\end{array}$ & Ashanti & $\begin{array}{l}\text { Brong } \\
\text { Ahafo }\end{array}$ & $\begin{array}{l}\text { Eastern } \\
\text { \& Volta }\end{array}$ & \\
\hline \multicolumn{7}{|l|}{ Experienced difficulty in selling crops } \\
\hline No difficulty & 44 & 44 & 35 & 49 & 43 & 43 \\
\hline Difficulty & 34 & 35 & 37 & 32 & 40 & 30 \\
\hline Did not sell harvested crops & 22 & 21 & 28 & 20 & 17 & 27 \\
\hline Experienced or anticipate difficulty in accessing farm inputs: & 43 & 43 & 41 & 46 & 34 & 39 \\
\hline Seed & 19 & 20 & 25 & 18 & 20 & 20 \\
\hline Fertilizer & 67 & 67 & 69 & 68 & 60 & 73 \\
\hline Agrochemicals & 67 & 70 & 63 & 76 & 50 & 53 \\
\hline Farm machinery & 22 & 22 & 13 & 26 & 20 & 20 \\
\hline Other inputs & 15 & 17 & 19 & 20 & 0 & 7 \\
\hline Anticipates changing cropping practices due to COVID-19 & 4 & 5 & 6 & 2 & 20 & 0 \\
\hline \multicolumn{7}{|l|}{ Anticipated changes in crop demand due to COVID-19: } \\
\hline No change & 20 & 19 & 15 & 21 & 20 & 18 \\
\hline Increase & 30 & 29 & 35 & 29 & 20 & 33 \\
\hline Decrease & 49 & 49 & 48 & 44 & 63 & 46 \\
\hline Do not know & 11 & 12 & 7 & 14 & 11 & 10 \\
\hline \multicolumn{7}{|l|}{ Anticipated changes in crop prices due to COVID-19: } \\
\hline No change & 10 & 11 & 9 & 13 & 6 & 10 \\
\hline Increase & 21 & 22 & 24 & 23 & 17 & 13 \\
\hline Decrease & 56 & 53 & 56 & 48 & 66 & 72 \\
\hline Do not know & 11 & 12 & 11 & 13 & 9 & 8 \\
\hline Observations & 249 & 206 & 54 & 117 & 35 & 39 \\
\hline
\end{tabular}

Source: IFPRI/FMMS phone survey of fish farmers (June 2020).

\subsection{Other livelihoods}

Aside from fish farming and crop farming, most respondents have other livelihoods. According to the 2019 baseline survey, 20 percent of pond farmers in Ashanti sourced more than half of their household income from fish farming, whereas only between 8 and 10 percent of pond farmers in Brong Ahafo, Eastern, and Volta did so (Ragasa et al. 2020). The majority of pond farmers rely on other livelihood sources. In terms of main occupation or livelihood of the fish farm owner/manager, 30 percent reported crop farming (mainly pond farmers), 23 percent reported own nonfarm businesses, 14 percent reported nonfarm wage employment, 9 percent reported capture fisheries (mainly cage farmers), and 7 percent reported farm wage employment (mainly pond farmers). Cage farmers rely more on fish farming as a livelihood than pond farmers do - 48 percent of cage farmers in Eastern and 38 percent of cage farmers in Volta sourced more than half of their household income from fish farming.

The most common livelihoods were own nonfarm business or wage/salary employment (Table 4). Remittances from migrant workers were not common among fish farmers, reported by only 3 percent of respondents. Sixty-four percent reported that their livelihoods (other than fish and crop farming) were affected by COVID-19, with 76 percent reporting a decrease in household income due to COVID-19 (Table 4). Farmers' main mechanisms for coping with this loss of income were to use savings, reduce nonfood expenditures, and borrow money. Eleven percent of respondents reported reducing food consumption or expenditure because of COVID-19. One farmer said, "Now money is scarce, [and] getting loans from family members is even difficult." The main effect of 
COVID-19 on livelihoods was lower sales or revenue from respondents' own business. Others reported difficulty in accessing inputs or raw materials for their business and increased prices of major inputs or raw materials. However, only 6 percent of the fish farmers surveyed received COVID-19 related assistance or transfers from the government or a non-governmental organization.

Table 4. Effects of the COVID-19 crisis on other livelihoods and household income of surveyed fish farmers

\begin{tabular}{|c|c|c|c|c|c|c|}
\hline \multirow[b]{2}{*}{ Indicators } & \multirow[t]{2}{*}{ All } & \multicolumn{4}{|c|}{ Pond } & \multirow[t]{2}{*}{ Cage } \\
\hline & & $\begin{array}{l}\text { All } \\
\text { pond }\end{array}$ & Ashanti & $\begin{array}{l}\text { Brong } \\
\text { Ahafo }\end{array}$ & $\begin{array}{l}\text { Eastern } \\
\text { \& Volta }\end{array}$ & \\
\hline \multicolumn{7}{|l|}{ Other livelihoods, percent of fish farmers surveyed } \\
\hline Food trading & 1 & 1 & 3 & 1 & 0 & 1 \\
\hline Other trading business & 13 & 13 & 12 & 16 & 6 & 12 \\
\hline Other own business & 28 & 30 & 37 & 25 & 38 & 22 \\
\hline Wage/salary employment & 17 & 17 & 13 & 19 & 17 & 13 \\
\hline Remittances & 3 & 3 & 1 & 4 & 4 & 4 \\
\hline Other (mainly livestock production) & 8 & 9 & 5 & 11 & 8 & 6 \\
\hline None & 29 & 26 & 29 & 24 & 27 & 41 \\
\hline $\begin{array}{l}\text { Other livelihoods were affected by COVID, percent of other } \\
\text { livelihoods }\end{array}$ & 64 & 64 & 72 & 62 & 58 & 65 \\
\hline \multicolumn{7}{|l|}{ Mechanisms of effect on livelihood: } \\
\hline Lost job & 1 & 1 & 3 & 0 & 0 & 3 \\
\hline Company reduced my salary & 4 & 3 & 5 & 3 & 0 & 10 \\
\hline Business shut down & 5 & 5 & 5 & 3 & 14 & 6 \\
\hline Low market and low revenue from business & 80 & 82 & 77 & 83 & 86 & 68 \\
\hline Difficulty accessing inputs for business & 19 & 19 & 18 & 15 & 32 & 23 \\
\hline Increase in price of major inputs & 15 & 18 & 23 & 17 & 14 & 3 \\
\hline Other & 13 & 12 & 8 & 13 & 18 & 13 \\
\hline \multicolumn{7}{|l|}{ Coping strategies for income loss: } \\
\hline Used bank or cash savings & 53 & 54 & 47 & 51 & 70 & 52 \\
\hline Reduced non-food consumption and expenditure & 38 & 39 & 44 & 39 & 35 & 35 \\
\hline Reduced food consumption & 11 & 13 & 11 & 17 & 3 & 6 \\
\hline Borrowed money & 18 & 16 & 19 & 18 & 8 & 23 \\
\hline Bought food or household necessities on credit & 7 & 6 & 5 & 5 & 8 & 9 \\
\hline Sold off assets, e.g., jewellery, mobile, or furniture & 1 & 1 & 0 & 3 & 0 & 0 \\
\hline Did nothing & 14 & 13 & 7 & 16 & 10 & 15 \\
\hline Other & 13 & 15 & 9 & 15 & 25 & 8 \\
\hline $\begin{array}{l}\text { Received cash transfer or other assistance from } \\
\text { government or NGO since March } 2020\end{array}$ & 6 & 7 & 9 & 5 & 10 & 3 \\
\hline Observations, other livelihoods & 280 & 213 & 57 & 116 & 40 & 65 \\
\hline
\end{tabular}

Source: IFPRI/FMMS phone survey of fish farmers (June 2020). NGO = non-governmental organization.

\section{INTERVIEWS WITH OTHER VALUE CHAIN ACTORS}

Other actors along the value chain were adversely affected by reduced tilapia demand and consequent disruptions in the markets, although the effects vary across location, actor type, and stage of production. Despite the exemption of food chain actors from lockdown measures in Ghana, many of fish value chain actors - from feed and fingerling producers to traders to consumers - still experienced various negative effects. 
Upstream, one feed importer reported that sales fell by 50 percent because of the lockdown and social distancing restrictions imposed by the government. In the short term, the importer's supply was not affected because of sufficient available stock. In the long term, however, the importer expects lower demand for feeds and slower importation. "Before the crisis, we could get feed supplies in three weeks to one month, but now it takes about a month or two," says the feed importer. A medium-sized feed-producing company that had just opened when COVID-19 hit reported that it has been struggling to survive.

Raanan, a large local feed producer and exporter of feeds to other African countries with production capacity of 4,000 tons per month, has been affected by reduced feed demand and sales. The firm indicated that local sales of feed dropped by about 50 percent because of the lockdown and social distancing restrictions. The addition of border closures reduced exports of Raanan feed to neighboring countries by about 20 percent. Raanan sources 30 percent of its main raw materials - maize, soya, and fish meal - from outside Ghana. The company had sufficient stock of raw materials for the short term; however, "due to the impact of the lockdown and social distancing restrictions on banking services, it was difficult to make payments," says a Raanan representative. The price of local yellow maize, a major raw material of local feed, has been increasing (SRID raw datasets). In addition, "changes in global supply chains, with potential increases in the price of imported raw materials, will likely affect local feed production and increase feed prices over the long term," added a Raanan representative.

Feed prices have not increased significantly to date, but disruptions in the global value chain and trade restrictions will likely affect feed prices in the near future. The crisis has already affected producers' access to feeds, which account for between 70 and 80 percent of the total cost of farmed fish production (Ragasa et al. 2018; Ragasa et al. 2020). Some farmers and hatchery operators just starting or in the middle of the production cycle experienced greater difficulty accessing feeds. A farmer in Ashanti said that, because of lockdown exceptions for buses and food value chain actors, he could still place feed orders and get them transported to the bus station in Tema. However, with few local vehicles available for hire, he cannot transport the feed from the bus station to his farm in Kumasi. Tilapia growth is very sensitive to irregular or insufficient feeding.

Unlike access to feeds, producers' access to fingerlings, another major input to fish production, does not seem to be affected in the short term. The crisis has not yet affected breeding or brood stock multiplication activities. Actors do not anticipate short-term disruptions in the demand for fingerlings, but acknowledged that lower demand for tilapia will likely produce a subsequent negative effect on demand for fingerlings. Hatchery operators have already started to slow their fingerling production. Hatchery operators with fingerlings ready to sell to growout farmers also experienced delays in sales because of restrictions on movement. Farmers who ordered fingerlings before COVID-19 could not get them during the lockdown. This situation improved after the lockdown, and hatchery operators could eventually sell their fingerlings. The hatchery operators interviewed said, however, that they will wait and reassess the situation before they start producing again, which will likely reduce overall tilapia and catfish production in 2020.

Most operations of fish aggregators halted during the lockdown because of low demand from restaurants, hotels, chop bars, and household consumers. Before the crisis, one trader interviewed sold 2 to 3 tons of tilapia per week from a pool of 50 farmers. With low demand from restaurants and hotels, that trading business contracted by 70 percent - the trader now sources only from three farmers and focuses only on home deliveries.

Downstream in the food chain, consumers seem to have lessened their shopping frequency and food consumption both during and after the lockdown. A consumer exit survey conducted in 2018 found that most tilapia shoppers in Accra ate tilapia at least once per week and most purchased it every week or more frequently (Ragasa et al. 2019). But, 52 percent of consumers surveyed in 
June 2020 reported that they had reduced eating out or their purchases for home consumption during the lockdown, and 36 percent reported that even after the lockdown ended they have reduced their purchases compared to before COVID (Table 5). Half of the consumers surveyed reported that tilapia prices went up by 30 percent on average during the COVID-19 crisis and have remained high even after the lockdown ended (Annex Tables 4 and 5).

Table 5. Changes in tilapia purchases and price during the COVID-19 crisis, percent of consumers surveyed

\begin{tabular}{lccccc}
\multicolumn{1}{c}{ Indicator } & Tilapia & Other fish & $\begin{array}{c}\text { Local } \\
\text { chicken }\end{array}$ & $\begin{array}{c}\text { Imported } \\
\text { chicken }\end{array}$ & $\begin{array}{c}\text { Imported } \\
\text { rice }\end{array}$ \\
$\begin{array}{l}\text { Reduced eating out or purchases for home during lockdown } \\
\text { Reduced eating out or purchases for home after lockdown }\end{array}$ & 52 & 42 & 52 & 33 & 42 \\
$\begin{array}{l}\text { Perceived changes in tilapia prices: } \\
\quad \text { Prices remained the same }\end{array}$ & 46 & 24 & 36 & 28 & 16 \\
$\quad$ Prices went up & 51 & 34 & 38 & 31 & 68 \\
$\quad$ Prices went down & 3 & 2 & 1 & 1 & 1 \\
\hline
\end{tabular}

Source: IFPRI/FMMS phone survey of consumers in Accra (June 2020). Prices in 2018 and 2018 are in Annex Table 4.

In terms of consumption based on seven-day food recall, 23 percent of consumers surveyed decreased the frequency and 17 percent decreased the quantity of their fresh tilapia consumption (Annex Table 6). Twenty-four percent of consumers surveyed decreased the frequency of processed or smoked tilapia consumption, and 4 percent decreased the quantity consumed.

Reduced purchase and consumption result mainly from decreased availability (Annex Tables 6 and 7). Thirty percent of consumers surveyed said they observed decreased availability of fresh tilapia during lockdown, and 10 percent reported decreased availability after lockdown. Thirty-six percent reported decreased availability of processed tilapia during lockdown, and 6 percent reported reduced availability after lockdown. Other reasons given for reduced purchases and consumption are higher tilapia prices (Table 5) and reduced incomes and purchasing power due to COVID-19 (consumer survey data).

\section{SUMMARY AND IMPLICATIONS}

The ISKNV outbreak and the COVID-19 pandemic exposed the vulnerabilities of the aquaculture value chain in Ghana and highlighted the urgent need for readjustment and support for the sector. All actors interviewed reported being affected by restrictions on movement and by reduced demand for tilapia due to closures in the tourism and hospitality industries. The crisis has reduced incomes for most actors along the value chain, and the resulting decline in investment funding is anticipated to constrain future aquaculture production. Table 6 shows current and expected future impacts of the crisis on the different actors - from consumers downstream to input suppliers upstream.

The immediate effects of COVID-19 on fish farming operations also reveal some heterogeneity. The highest proportions of those reporting difficulty selling fish, difficulty finding labor, and facing higher wage bills were in Ashanti and Brong Ahafo. In terms of crop farming, similarly farmers in Ashanti and Brong Ahafo also reported difficulty accessing inputs and selling their crops. 
Table 6. Summary of effects of the COVID-19 crisis on tilapia value chain actors in Ghana

\begin{tabular}{|c|c|c|}
\hline Stage of chain & Actors & Observed and anticipated effects \\
\hline $\begin{array}{l}\text { Fish } \\
\text { consumption }\end{array}$ & $\begin{array}{l}\text { Hotels } \\
\text { Restaurants } \\
\text { Chop bars \& tilapia } \\
\text { joints } \\
\text { Household } \\
\text { consumers }\end{array}$ & $\begin{array}{l}\text { - Closures of hotels, restaurants, and chop bars led to limited demand for } \\
\text { tilapia, but demand is slowly and cautiously bouncing back. } \\
\text { - Compared to the pre-COVID period, half of consumers surveyed in Accra } \\
\text { reduced their tilapia purchases during lockdown and } 36 \text { percent reduced their } \\
\text { purchases after lockdown. } \\
\text { - Half of consumers reported tilapia prices on average went up by } 30 \text { percent. }\end{array}$ \\
\hline $\begin{array}{l}\text { Fish mark } \\
\text { and pro }\end{array}$ & $\begin{array}{l}\text { Traders } \\
\text { Retailers } \\
\text { Processors }\end{array}$ & $\begin{array}{l}\text { - Operations reduced substantially during lockdown } \\
\text { - Opportunities for wage-earners for scaling and gutting tilapia were reduced. } \\
\text { - Closures of food markets not adhering to social distancing protocols limited } \\
\text { food access for many consumers. }\end{array}$ \\
\hline $\begin{array}{l}\text { Fish } \\
\text { proc }\end{array}$ & $\begin{array}{l}\text { Grow-out pond and } \\
\text { cage farmers } \\
\text { (micro, small, } \\
\text { medium, large), } \\
\text { Wage and salary } \\
\text { earners }\end{array}$ & $\begin{array}{l}\text { - Farmers of all sizes with tilapia ready to sell experienced reduced sales } \\
\text { during and after lockdown and faced the increased costs of continued } \\
\text { feeding: } \\
\text { - Many farmers had to sell at lower prices - distress sales. } \\
\text { One farmer reported a drop in the average farmgate price for size } 1 \text { tilapia } \\
\text { from GHC } 14.50 / \mathrm{kg} \text { to } \mathrm{GHC} 12 / \mathrm{kg} \text {. } \\
\text { Of those harvesting during the crisis, } 56 \text { percent of pond farmers and } 72 \\
\text { percent of cage farmers experienced difficulty selling. } \\
\text { The main reasons were lower demand or no buyers, lower tilapia prices, } \\
\text { and higher transportation costs. } \\
\text { Small-scale farmers with ongoing production experienced difficulties in } \\
\text { accessing inputs: } \\
54 \text { percent of those growing tilapia experienced difficulties accessing } \\
\text { inputs } \\
\text { - } 97 \text { percent experienced difficulty accessing feeds } \\
\text { In addition, farmers reported difficulty accessing fingerlings, fertilizers or } \\
\text { other chemicals, and farm machinery (14 percent each) } \\
59 \text { percent reported increases in input prices compared to January before } \\
\text { COVID-19. } \\
\text { Average increase of feed prices was roughly GHC } 2.00 / \mathrm{kg} \text {. } \\
\text { Average increase of fingerling price was GHC } 0.27 \text { per piece. }\end{array}$ \\
\hline $\begin{array}{l}\text { Feed } \\
\text { production }\end{array}$ & $\begin{array}{l}\text { Feed producers } \\
\text { Feed importers }\end{array}$ & $\begin{array}{l}\text { - Two feed producers and importers reported sales falling by } 50 \text { percent during } \\
\text { the lockdown. But, they say that sales since have slowly started to recover. } \\
\text { - Feed exports decreased by } 20 \text { percent. } \\
\text { - Farmers experienced logistical difficulties in importing feeds and feed } \\
\text { ingredients. Moreover, they expect difficulties in making payments. }\end{array}$ \\
\hline $\begin{array}{l}\text { Fish seed } \\
\text { production }\end{array}$ & $\begin{array}{l}\text { Brood stock } \\
\text { multipliers } \\
\text { Hatcheries }\end{array}$ & $\begin{array}{l}\text { - Sales fell during lockdown, but orders of fingerlings have since recovered. } \\
\text { - Several hatcheries anticipate lowered production because of fewer orders of } \\
\text { fingerlings. }\end{array}$ \\
\hline $\begin{array}{l}\text { Input } \\
\text { distribution }\end{array}$ & Transporters & $\begin{array}{l}\text { - Some private vehicle operators were reluctant to operate, partly they feared } \\
\text { contracting the virus } \\
\text { - Others hiked the prices of the transportation services they offered. }\end{array}$ \\
\hline
\end{tabular}

Source: Authors' compilation based on the interviews.

More data and assessment are needed to rigorously monitor and evaluate the medium- and long-term impacts of the COVID-19 crisis on the aquaculture sector and on the income and nutrition of aquaculture value chain actors and to effectively target support. To assist in this monitoring and evaluation, IFPRI is continuing phone surveys with a large sample of fish farmers and consumers. Although the private sector has largely driven the aquaculture value chain, the current crisis warrants greater government support. This first round of the phone survey and this assessment indicates that the government's COVID-19 response and sectoral programs should consider including strategies for quicker recovery and greater resilience of aquaculture and to minimize setbacks to realizing the goals of the Aquaculture for Food and Jobs program. Our recommendations based on the initial assessment are as follows.

First, the weaker demand (lower purchasing power) of consumers of fresh tilapia and other more expensive products point to the need to aggressively explore and expand markets and to 
provide market intelligence, cold chain infrastructure, and greater industry coordination. Many neighboring countries - including Cameroon, Côte d'Ivoire, and Niger - rely on fish imports, including tilapia, mainly from China (Ragasa et al. 2018; FishStatJ database for updates ${ }^{4}$ ). With trade restrictions and greater concerns regarding food safety and the spread of COVID-19, countries are turning to local or regional production. ${ }^{5}$ Now is an opportune time to strengthen regional trade, which can offer a win-win strategy for producers and consumers in West Africa and the continent. Ghana is in a good position to act as a producer of fresh and frozen tilapia and catfish and fish feed for the region.

Second, an initial disconnect exists between supply and demand of tilapia: value chain actors do not know what to expect from the market. On one hand, many farmers had to sell at lower prices (distress sales). On the other hand, half of surveyed consumers in June reported a 30 percent increase in tilapia prices (the other half did not experience any change in tilapia prices). To link demand and supply that were disconnected during the COVID-19 related partial lockdown and social distancing measures, mobilize digital platforms, courier services, and home delivery options. There also is need to stimulate local demand and build consumer confidence by reopening restaurants and chop bars with appropriate precautionary measures and improved sanitation. Farmers and other value chain actors need intensified market intelligence and information dissemination for better coordination and matching of supply and demand. Digital platforms, such as WhatsApp groups between farmers, other value chain actors, and traders, should be explored to help in industry coordination. Growing tilapia of smaller sizes may help farmers target their produce to household consumers while they wait for the tourism industry to bounce back. Exploring fish diversification (catfish and other species) can also reduce risk and cater to demand for a more diverse range of fish. Fish processing - smoking, salting, drying, and processing into value-added products - could increase shelf life and preserve farm profits.

Third, 82 percent of surveyed farmers planned to stock or restock during the next cycle, which is encouraging. Roughly 40 percent anticipated increases in consumer demand and tilapia prices, while another 40 percent anticipated decreases in tilapia demand and prices. This variation in response indicates an opportunity to disseminate up-to-date market intelligence to guide production and investment decisions by farmers and value chain actors. Supporting and mobilizing industry and producer associations could help address logistical difficulties during the crisis, so these associations can monitor transportation prices, help check other opportunistic behavior, and better coordinate value chain actors. The need to strengthen aquaculture extension, including radio and mobile platforms, is more essential during the COVID-19 crisis than ever. Some farmers indicated that neighbors who were laid off or have lost businesses because of the crisis now show interest in fish farming - strengthening aquaculture extension can help nudge these potential farmers into profitable aquaculture businesses.

Fourth, support of local fish farming can be achieved through temporary subsidies or loan programs for farmers and input suppliers. The sector, unlike cocoa or maize (Ragasa and Byerlee 2012; Ragasa et al. 2013), has not benefitted much from public policies, like subsidies and other public investments. Reduced incomes from livelihood sources, all affected by COVID-19, have reduced private funds available for investing in fish farming. Programs supporting the sector may need to reduce project expectations and provide short-term financial support to help fish farmers cope with their production and marketing challenges. Small input packages, such as free fingerlings or a bag of starter feeds, may help farmers greatly in times of uncertainty. This support

\footnotetext{
${ }^{4}$ http://www.fao.org/fishery/statistics/software/fishstatj/en

${ }^{5} \mathrm{https}$ ///www.reuters.com/article/us-health-coronavirus-kenya-fish/coronavirus-provides-unexpected-boost-for-kenyan-fishermenidUSKBN21A1H8
} 
will also help small-scale hatcheries and feed producers - critical actors in the value chain - to have constant orders of fingerlings and feeds and stay in business.

Lastly, programs and firms need to protect workers through provision of protective gear, free COVID-19 testing, and improvements in sanitation. The 2019 IFPRI baseline survey found that fish facilities have notoriously poor sanitation. One fish processing plant in Ghana shut down because more than 500 workers were infected with COVID-19. ${ }^{6}$ This event serves as a reminder of the need to protect vital food workers. Fish mortality in early 2019 and now the COVID-19 virus serves, in turn, as reminders of the crucial importance of proper aquaculture practices, including sanitation, for improved economic performance and resilience of aquaculture.

${ }^{6}$ https://www.reuters.com/article/us-health-coronavirus-ghana/president-says-one-person-infected-533-with-coronavirus-at-ghana-fishfactory-idUSKBN22N02J 


\section{REFERENCES}

Andam, K.S., C. Ragasa, S. Asante, and S. Amewu. 2019. Can local products compete against imports in West Africa? Supply-and demand-side perspectives on chicken, rice, and tilapia in Accra, Ghana. IFPRI Discussion Paper 1821. Washington, DC: International Food Policy Research Institute (IFPRI).

Harris, J., L. Depenbusch, A.A. Pal, R.M. Nair, and S. Ramasamy. 2020. "Food system disruption: Initial livelihood and dietary effects of COVID-19 on vegetable producers in India." Food Security 12: 841-851.

Headey, D., and M. Ruel. 2020. "The COVID-19 nutrition crisis: What to expect and how to protect. Analyses on the impacts of the COVID-19 pandemic on national and global food and nutrition security, poverty, and development." IFPRI blog series available at https://www.ifpri.org/blog/COVID-19-nutrition-crisis-whatexpect-and-how-protect.

Hirvonen, K., G.T. Abate, and A. de Brauw. 2020. Food and nutrition security in Addis Ababa, Ethiopia during COVID-19 pandemic - May 2020 report. Ethiopia Strategy Support Program Working Paper 143. Addis Ababa: International Food Policy Research Institute (IFPRI).

Kassam, L., and A. Dorward. 2017. "A comparative assessment of the poverty impacts of pond and cage aquaculture in Ghana." Aquaculture 470: 110-12.

Kudah, C. 2020. "Fish farms witness huge drop in sales due to COVID-19," online news accessed on June 202020 at https://citibusinessnews.com/fish-farms-witness-huge-drop-in-sales-due-to-COVID-19/

Lambrecht, I., C. Ragasa, K. Mahrt, Z.W. Aung, and M. Wang. 2020. Monitoring the impact of COVID-19 in Myanmar: Agricultural production and rural livelihoods in two irrigation schemes - June 2020 survey round. Myanmar SSP Policy Note 20. Washington, DC: International Food Policy Research Institute (IFPRI).

Ragasa, C., and D. Byerlee. 2012. New Directions for Revitalizing the National Agricultural Research System in the Context of Growing Private Sector R\&D. Transforming Agriculture Conference, November 8-9, Accra, Discussion Note \# 017. Accra: International Food Policy Research Institute (IFPRI).

Ragasa, C., S.K. Agyakwah, R. Asmah, E.T.-D. Mensah, and S. Amewu. 2020. Characterization of fish farming practices and performance: Baseline study and implications for accelerating aquaculture development in Ghana. IFPRI Discussion Paper 1937. Washington, DC: International Food Policy Research Institute (IFPRI).

Ragasa, C., K.S. Andam, S. Amewu, and S. Asante. 2019. Consumer demand and willingness to pay for safe food in Accra, Ghana: Implications for public and private sectors' roles in food safety management. IFPRI Discussion Paper 1795. Washington, DC: International Food Policy Research Institute (IFPRI).

Ragasa, C., K.S. Andam, D.S. Kufoalor, and S. Amewu. 2018. A blue revolution in sub-Saharan Africa? Evidence from Ghana's tilapia value chain. Ghana Strategy Support Program Working Paper 49. Accra: International Food Policy Research Institute (IFPRI).

Ragasa, C., A. Dankyi, P. Acheampong, A.N. Wiredu, A. Chapoto, M. Asamoah, and R. Tripp. 2013. Patterns of Adoption of Improved Maize Technologies in Ghana. Ghana Strategy Support Program Working Paper 36. Accra: International Food Policy Research Institute (IFPRI).

Ramírez-Paredez, J.G., R.K. Paley, W. Hunt, S.W. Feist, D.M. Stone, T.R. Field, D.J. Haydon, P.A. Ziddah, M. Nkansa, E.K. Pecku, J.A. Awuni, J. Guilder, J. Gray, S. Duodu, T.S. Wallis, and D.W. Verner-Jeffreys. 2019. "First detection of infectious spleen and kidney necrosis virus (ISKNV) associated with massive mortalities in farmed tilapia in Africa." bioRxiv. https://doi.org/10.1101/680538 


\section{ANNEXES}

Annex Table 1. Demographic statistics for the samples for the 2020 phone survey and 2018 face-to-face survey of consumers in Accra, percent of respondents

\begin{tabular}{|c|c|c|}
\hline & $\begin{array}{c}\text { All } \\
\text { (phone survey, 2020) }\end{array}$ & $\begin{array}{c}\text { All } \\
\text { (face-to-face survey, 2018) }\end{array}$ \\
\hline \multicolumn{3}{|l|}{ Education level } \\
\hline No schooling or up to primary school & 23 & 23 \\
\hline Junior High + vocational & 31 & 30 \\
\hline Senior High + diploma & 33 & 34 \\
\hline College degree or higher & 12 & 12 \\
\hline Missing education information & 1 & 1 \\
\hline \multicolumn{3}{|l|}{ Gender } \\
\hline Female & 81 & 81 \\
\hline Male & 19 & 20 \\
\hline Respondent's age (years) & 40 & 40 \\
\hline $20-35$ & 41 & 40 \\
\hline $36-60$ & 52 & 54 \\
\hline $61+$ & 6 & 6 \\
\hline Missing age information & 0 & 1 \\
\hline Household size (number of member) & 5 & 4 \\
\hline \multicolumn{3}{|l|}{ Income group /a } \\
\hline Poor 1 (poorest) (<GHC400) & 9 & 9 \\
\hline Poor 2 (GHC400-999) & 38 & 34 \\
\hline Poor 3 (GHC1000-2000) & 23 & 25 \\
\hline Nonpoor (>GHC2000) & 13 & 18 \\
\hline Missing income information & 16 & 13 \\
\hline \multicolumn{3}{|l|}{ Marriage status } \\
\hline Married & 65 & - \\
\hline Single & 24 & - \\
\hline Divorced or widowed & 10 & - \\
\hline Refused to answer & 1 & \\
\hline Observations & 423 & 1,203 \\
\hline
\end{tabular}

Source: IFPRI/FMMS phone survey of consumers in Accra (June 2020)

Note: /a Income group is based on 2018 data. The basis for these income groups is the GLSS 7 poverty profile (GSS 2018).

- The lower poverty line is $\mathrm{GH} \phi 792.05$ per adult per year (extreme poverty). Individuals whose total expenditure falls below this line are considered to be in extreme poverty, since even if they allocated their entire budget to food, they would not be able to meet their minimum nutrition requirements. Assuming two adults in a household, the extreme poverty limit would be about GH $\phi 1600$ per household per year. The majority of the sample consumers are in this category, so we further broke them down into three groups: poor 1 (poorest) (<GHC400), poor 2 (GHC400-999), and poor 3 (GHC1000-2000).

- The upper poverty line is $\mathrm{GH} \phi 1,314$ per adult per year. Individuals consuming above this level can be considered able to purchase enough food to meet their nutritional requirements and their basic non-food needs. Assuming two adults in a household, this would be about $\mathrm{GH} \phi 1600$ per household per year. Households in this category are referred to here as nonpoor 
Annex Table 2. Demographic statistics from the 2020 farmer phone survey and the 2019 face-to-face survey of small-scale farmers in major aquaculture and crop producing regions, percent of respondents

\begin{tabular}{|c|c|c|}
\hline & $\begin{array}{c}\text { All } \\
\text { (phone survey, } \\
2020)\end{array}$ & $\begin{array}{c}\text { All } \\
\text { (face-to-face } \\
\text { survey, 2019) }\end{array}$ \\
\hline \multicolumn{3}{|l|}{ Education Level } \\
\hline No schooling or up to primary school & 20 & 19 \\
\hline Junior High + vocational & 36 & 37 \\
\hline Senior High + diploma & 19 & 22 \\
\hline College degree or higher & 23 & 22 \\
\hline \multicolumn{3}{|l|}{ Gender } \\
\hline Female & 7 & 6 \\
\hline Male & 92 & 94 \\
\hline Respondent's age (years old) & 49 & 49 \\
\hline Less than 35 & 17 & 18 \\
\hline $36-60$ & 62 & 62 \\
\hline Over 61 & 20 & 20 \\
\hline \multicolumn{3}{|l|}{ Asset quintile } \\
\hline 1 (poorest) & 19 & 20 \\
\hline 2 & 20 & 20 \\
\hline 3 & 19 & 20 \\
\hline 4 & 21 & 20 \\
\hline 5 (wealthiest) & 20 & 20 \\
\hline \multicolumn{3}{|l|}{ Marriage Status } \\
\hline Married & 84 & 84 \\
\hline Single & 12 & 12 \\
\hline Divorced or widowed & 3 & 4 \\
\hline \multicolumn{3}{|l|}{ Region } \\
\hline Ashanti & 21 & 25 \\
\hline Brong-Ahafo area (Bono, Bono East, Ahafo) & 42 & 39 \\
\hline Eastern & 29 & 29 \\
\hline Volta & 8 & 7 \\
\hline Observations & 369 & 603 \\
\hline
\end{tabular}

Source: IFPRI/FMMS phone survey of sample fish and crop farmers (June 2020).

Annex Table 3. Effects of fish mortality in Lake Volta due to infectious spleen and kidney necrosis virus (ISKNV) on tilapia stocking and production, percent of cage farmers

\begin{tabular}{lc}
\multicolumn{2}{c}{ Indicators } \\
No effect of fish mortality & 12.0 \\
Stopped fish farming because of fish mortality & 10.1 \\
Reduced stocking by 75 percent because of fish mortality & 26.4 \\
Reduced stocking by 50 percent because of fish mortality & 36.8 \\
Reduced stocking by 25 percent because of fish mortality & 14.7 \\
\hline Observations & 77 \\
\hline
\end{tabular}

Source: IFPRI/FMMS phone survey of fish farmers (June 2020). 
Annex Table 4. Retail prices of chicken and tilapia in 2018 and 2019

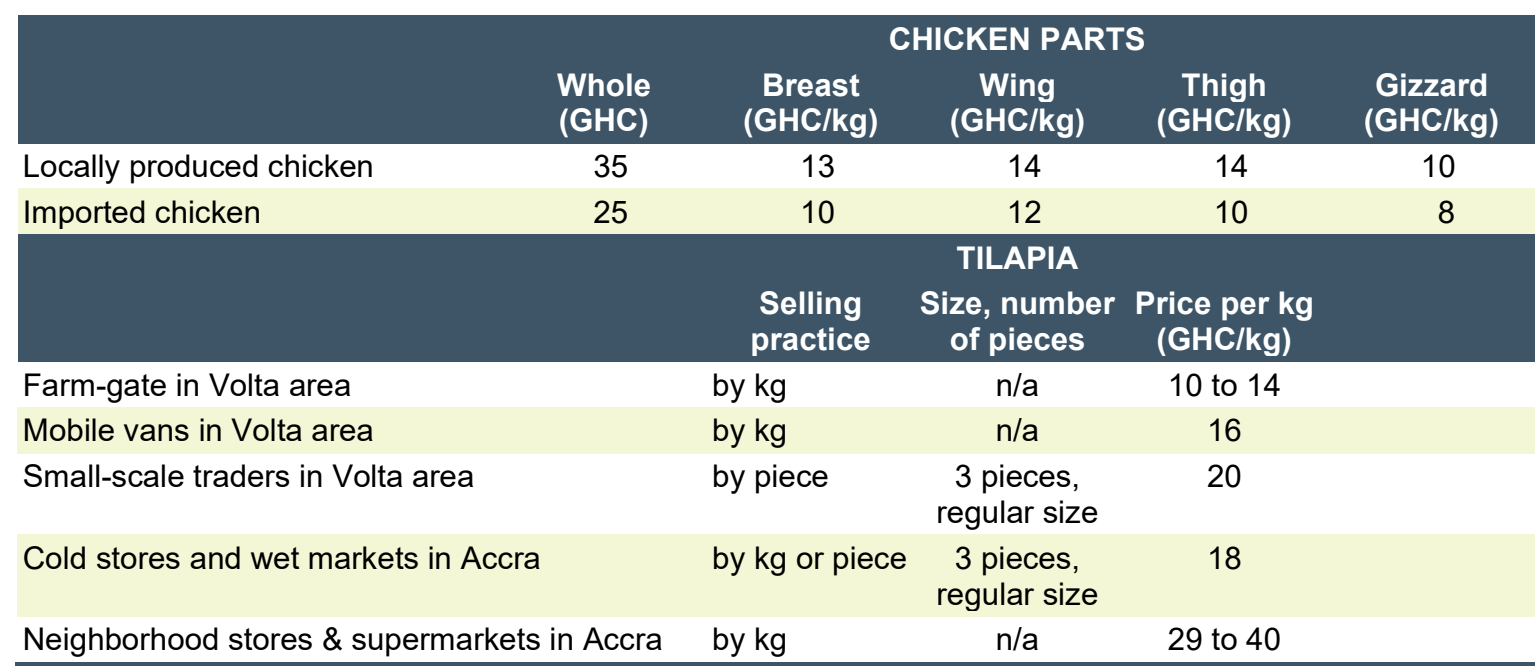

Source: IFPRI market surveys $(2018,2019)$. n/a = not applicable.

Annex Table 5. Comparison of prices of selected food items before the COVID-19 crisis and after lockdown, reports of consumers surveyed in Accra who reported price changes

\begin{tabular}{|c|c|c|}
\hline & Indicators & \\
\hline Tilapia & Price after lockdown, GHC/kg & 30.79 \\
\hline & Price difference before (February) and after lockdown (May \& June), \% & 30.3 \\
\hline Other fish & Price after lockdown, GHC/piece & 11.28 \\
\hline & Price difference, \% & 29.9 \\
\hline Catfish & Price after lockdown, GHC/piece & 9.79 \\
\hline & Price difference, $\%$ & 24.5 \\
\hline Salmon & Price after lockdown, GHC/piece & 8.25 \\
\hline & Price difference, $\%$ & 32.3 \\
\hline Tuna & Price after lockdown, GHC/kg & 18.08 \\
\hline & Price difference, $\%$ & 30.9 \\
\hline Local chicken & Price after lockdown, GHC/chicken & 41.51 \\
\hline & Price difference, $\%$ & 23.8 \\
\hline Imported chicken & Price after lockdown, GHC/kg & 13.08 \\
\hline & Price difference, $\%$ & 16.4 \\
\hline
\end{tabular}

Source: IFPRI/FMMS phone survey of consumers in Accra (June 2020). 
Annex Table 6. Food consumption and changes in consumption due to COVID-19 crisis reported by consumers surveyed in Accra

\begin{tabular}{|c|c|c|c|c|c|c|c|c|c|c|c|c|}
\hline & \multirow[b]{2}{*}{$\begin{array}{l}\text { Average } \\
\text { days } \\
\text { consumed } \\
\text { in last } 7 \\
\text { days }\end{array}$} & \multirow[b]{2}{*}{$\begin{array}{l}\text { Did not } \\
\text { consume } \\
\text { last } 7 \\
\text { days, } \%\end{array}$} & \multirow[b]{2}{*}{$\begin{array}{c}\text { If ate, } \\
\text { average } \\
\text { days } \\
\text { consumed } \\
\text { in last } 7 \\
\text { days }\end{array}$} & \multicolumn{3}{|c|}{$\begin{array}{c}\text { Frequency of consumption } \\
\text { compared to February, } \\
\% \text { change }\end{array}$} & \multicolumn{3}{|c|}{$\begin{array}{c}\text { Quantity consumed } \\
\text { compared to February, } \\
\% \text { change }\end{array}$} & \multicolumn{2}{|c|}{$\begin{array}{l}\text { Reported decreased } \\
\text { food availability }\end{array}$} & \multirow[b]{2}{*}{$\begin{array}{l}\text { Observa- } \\
\text { tions of } \\
\text { consump- } \\
\text { tion }\end{array}$} \\
\hline & & & & Same & Increase & Decrease & Same & Increase & Decrease & $\begin{array}{c}\text { During } \\
\text { lockdown } \\
\text { compared } \\
\text { to } \\
\text { February, } \\
\%\end{array}$ & $\begin{array}{c}\text { After } \\
\text { lockdown } \\
\text { compared } \\
\text { to } \\
\text { February, } \\
\%\end{array}$ & \\
\hline Tilapia - fresh & 0.6 & 72.8 & 2.1 & 71.7 & 5.0 & 23.3 & 79.2 & 4.2 & 16.7 & 30.0 & 10.0 & 120 \\
\hline Tilapia -processed & 0.5 & 76.2 & 2.2 & 73.3 & 2.9 & 23.8 & 81.9 & 3.8 & 14.3 & 36.2 & 6.7 & 105 \\
\hline Catfish - fresh & 0.0 & 98.4 & 1.6 & 71.4 & 0.0 & 28.6 & 71.4 & 0.0 & 28.6 & 57.1 & 14.3 & 7 \\
\hline Catfish - processed & 0.5 & 80.3 & 2.4 & 71.3 & 3.4 & 25.3 & 83.9 & 3.4 & 12.6 & 26.4 & 3.4 & 87 \\
\hline Other fish - fresh & 0.7 & 80.5 & 3.3 & 83.7 & 3.5 & 12.8 & 86.0 & 4.7 & 9.3 & 25.6 & 3.5 & 86 \\
\hline Other fish - processed & 3.0 & 28.8 & 4.2 & 79.6 & 4.8 & 15.6 & 82.2 & 5.4 & 12.4 & 31.5 & 9.9 & 314 \\
\hline Grains, roots, tubers & 6.5 & 0.0 & 6.5 & 86.8 & 8.6 & 4.5 & 76.4 & 11.3 & 12.2 & 32.9 & 9.1 & 441 \\
\hline Pulses & 0.7 & 67.3 & 2.2 & 75.0 & 9.0 & 16.0 & 84.0 & 9.7 & 6.3 & 22.9 & 4.2 & 144 \\
\hline Nuts and seeds & 0.7 & 70.3 & 2.4 & 73.3 & 8.4 & 18.3 & 81.7 & 6.9 & 11.5 & 22.1 & 4.6 & 131 \\
\hline Milk or other dairy product & 1.9 & 55.1 & 4.2 & 74.7 & 11.1 & 14.1 & 80.3 & 9.1 & 10.6 & 14.6 & 7.6 & 198 \\
\hline Meat & 2.3 & 39.9 & 3.9 & 80.4 & 6.8 & 12.8 & 81.5 & 6.0 & 12.5 & 22.3 & 3.4 & 265 \\
\hline Egg & 2.2 & 39.5 & 3.6 & 71.2 & 12.0 & 16.9 & 84.3 & 7.5 & 8.2 & 19.9 & 5.6 & 267 \\
\hline Dark leafy green vegetables & 2.0 & 45.8 & 3.8 & 69.9 & 17.2 & 13.0 & 79.5 & 17.6 & 2.9 & 21.3 & 6.3 & 239 \\
\hline Other vegetables. & 4.9 & 12.7 & 5.7 & 85.7 & 8.8 & 5.5 & 79.7 & 15.1 & 5.2 & 28.6 & 8.1 & 385 \\
\hline Fruits & 3.4 & 25.4 & 4.6 & 46.5 & 42.6 & 10.9 & 49.8 & 46.2 & 4.0 & 33.1 & 11.9 & 329 \\
\hline Fried or processed foods & 0.7 & 80.0 & 3.5 & 77.3 & 5.7 & 17.0 & 80.7 & 6.8 & 12.5 & 36.4 & 6.8 & 88 \\
\hline Sugar, sweetened beverages & 1.3 & 63.7 & 3.5 & 74.4 & 6.9 & 18.8 & 80.6 & 5.6 & 13.8 & 12.5 & 1.9 & 160 \\
\hline
\end{tabular}

Source: IFPRI/FMMS phone survey of consumers in Accra (June 2020). 
Annex Table 7. Food consumption and changes in consumption due to COVID-19 crisis reported by fish farmers surveyed

\begin{tabular}{|c|c|c|c|c|c|c|c|c|c|c|c|c|c|}
\hline & \multirow[b]{2}{*}{$\begin{array}{c}\text { Average } \\
\text { days } \\
\text { consumed } \\
\text { in last } 7 \\
\text { days }\end{array}$} & \multirow[b]{2}{*}{$\begin{array}{l}\text { Did not } \\
\text { consume } \\
\text { last } 7 \\
\text { days, } \%\end{array}$} & \multirow{2}{*}{$\begin{array}{l}\text { If ate, } \\
\text { average } \\
\text { days } \\
\text { consumed } \\
\text { in last } 7 \\
\text { days }\end{array}$} & \multicolumn{3}{|c|}{$\begin{array}{c}\text { Frequency of consumption } \\
\text { compared to February, } \\
\% \text { change }\end{array}$} & \multicolumn{3}{|c|}{$\begin{array}{c}\text { Quantity consumed } \\
\text { compared to February, } \\
\% \text { change }\end{array}$} & \multicolumn{3}{|c|}{$\begin{array}{l}\text { Decreased food availability } \\
\text { during COVID-19 crisis? }\end{array}$} & \multirow[b]{2}{*}{$\begin{array}{l}\text { Observa- } \\
\text { tions of } \\
\text { consump } \\
\text {-tion }\end{array}$} \\
\hline & & & & Increased & Decrease & Same & Increase & Decrease & Same & $\begin{array}{c}\text { No } \\
\text { decrease }\end{array}$ & Decrease & $\begin{array}{l}\text { Does not } \\
\text { know }\end{array}$ & \\
\hline Tilapia - fresh & 1.5 & 62.6 & 4.1 & 9.0 & 20.5 & 70.5 & 7.4 & 18.9 & 73.8 & 74.6 & 24.6 & 0.8 & 122 \\
\hline Tilapia -processed & 2.2 & 46.1 & 4.1 & 9.4 & 16.6 & 74.0 & 12.7 & 17.7 & 69.6 & 74.6 & 24.3 & 1.1 & 181 \\
\hline Other fish - fresh & 1.6 & 60.5 & 4.0 & 11.9 & 22.2 & 65.9 & 15.9 & 25.4 & 58.7 & 81.7 & 12.7 & 5.6 & 126 \\
\hline Other fish - processed & 2.9 & 31.4 & 4.3 & 6.0 & 16.4 & 77.6 & 6.5 & 23.7 & 69.8 & 72.4 & 23.7 & 3.9 & 232 \\
\hline Grains, roots, tubers & 6.1 & 0.3 & 6.1 & 7.0 & 11.4 & 81.6 & 13.0 & 22.0 & 65.0 & 77.0 & 18.4 & 4.6 & 369 \\
\hline Pulses, beans, legumes & 0.9 & 65.9 & 2.8 & 16.5 & 19.3 & 64.2 & 15.6 & 24.8 & 59.6 & 79.8 & 15.6 & 4.6 & 109 \\
\hline Nuts and seeds & 1.1 & 59.1 & 2.7 & 14.2 & 17.9 & 67.9 & 11.2 & 26.1 & 62.7 & 85.1 & 9.7 & 5.2 & 134 \\
\hline Milk or other dairy product & 1.8 & 55.6 & 4.1 & 11.5 & 23.6 & 64.9 & 13.5 & 25.0 & 61.5 & 87.8 & 10.1 & 2.0 & 148 \\
\hline Meat & 2.9 & 25.9 & 3.9 & 11.5 & 28.1 & 60.4 & 14.2 & 32.3 & 53.5 & 80.0 & 16.2 & 3.8 & 260 \\
\hline Egg & 2.3 & 38.4 & 3.8 & 12.7 & 14.6 & 72.8 & 12.2 & 16.0 & 71.8 & 84.5 & 11.7 & 3.8 & 213 \\
\hline Dark leafy green vegetables & 2.8 & 34.8 & 4.4 & 10.3 & 12.1 & 77.6 & 17.0 & 12.6 & 70.4 & 85.7 & 9.0 & 5.4 & 223 \\
\hline Other vegetables. & 4.8 & 15.6 & 5.7 & 8.4 & 7.4 & 84.2 & 15.2 & 12.5 & 72.4 & 79.5 & 16.8 & 3.7 & 297 \\
\hline Fruits & 3.7 & 21.8 & 4.7 & 29.8 & 16.5 & 53.7 & 30.1 & 12.5 & 57.4 & 81.6 & 11.4 & 7.0 & 272 \\
\hline Fried or processed foods & 0.8 & 79.8 & 3.9 & 14.3 & 19.0 & 66.7 & 12.7 & 19.0 & 68.3 & 82.5 & 4.8 & 12.7 & 63 \\
\hline Sugar, sweetened beverages & 1.5 & 62.8 & 4.0 & 8.9 & 20.2 & 71.0 & 8.9 & 25.0 & 66.1 & 91.9 & 4.0 & 4.0 & 124 \\
\hline
\end{tabular}

Source: IFPRI/FMMS phone survey of fish farmers (June 2020). 


\section{ABOUT THE AUTHORS}

Catherine Ragasa is Senior Research Fellow in the Development Strategy and Governance Division (DSGD) of the International Food Policy Research Institute (IFPRI), based in Washington, DC. Sena Amewu and Seth Asante are Research Officers in the Ghana Strategy Support Program (GSSP) of IFPRI, based in Accra, Ghana.

\section{ACKNOWLEDGMENTS}

The authors gratefully acknowledge the funding support of the government of the Netherlands and the CGIAR Research Program on Policies, Institutions and Markets (PIM). We are grateful to Stella Appiah-Kubi and the enumerators at FMMS for implementing the phone surveys. We thank Karl Pauw for the feedback on the initial drafts. Most important, we thank the farmers, consumers, and other stakeholders who responded to our survey. 